\title{
The Unforgettable Indus River Flood-2010: A Review
}

Arshad Ali, Ghazala Nosheen and K. A. Khan

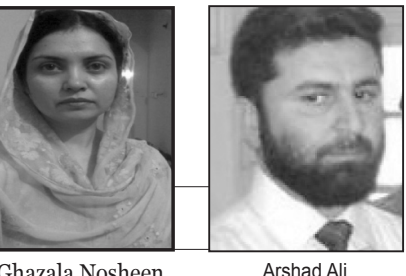

Ghazala Nosheen

Arshad Al

\begin{abstract}
Floods are the unannounced natural disasters that destroy both lives and infrastructures. In July 2010 a huge and unpredictable flood struck Pakistan, especially the catchment area of the River Indus, extending from the north part of Khyber Pakhtun Khwa (KPK) Province south to the Arabian Sea. The top five rainfall intensities recorded at Risalpur, Islamabad, Murree, Cherat and Ghari Dopatta were $415 \mathrm{~mm}, 394 \mathrm{~mm}, 373 \mathrm{~mm}, 372 \mathrm{~mm}$ and $346 \mathrm{~mm}$, respectively. The Indus Flood-2010 affected nearly 20 million people spreading over 36 districts of the country. The death toll recorded was nearly 1,800 persons. More than 10 million people were subjected to contaminated drinking water. The destruction to cotton, rice, sugar cane, and animal fodder was recorded as $3,000 \mathrm{~km}^{2}, 800 \mathrm{~km}^{2}, 800 \mathrm{~km}^{2}$, and $1000 \mathrm{~km}^{2}$, respectively. And about five hundred thousand tons of wheat was destroyed. The Indus Flood of 2010 caused an estimated 43 billion US dollar loss to Pakistan and adversely affected its Gross Domestic Product (GDP). It brought on both the financial crises and socio-political concerns (such as infiltration of the Taliban in the form of a relief supporter). Though this flood has left everlasting impacts on the people of Pakistan, they could be better handled if the government and relief agencies were more determined, honest and committed.
\end{abstract}

Key words: Indus River, Flood of 2010, Rainfall intensity, flood damage statistics, Pakistan

\section{Background}

The prevention of floods is a universally known substantial impracticality, though flood protection, management and mitigation are vitally important. Disastrous floods affect people irrespective of status, class and conditions. Floods destroy precious human properties and wealth and leave a number of potential hazardous health impacts on the affected communities. Flood prevention, management and mitigation are complex interdisciplinary issues for which some satisfactory solutions have been advanced, but for others no likely answers are as yet forthcoming (Tallat, Hashmi and Ali 2011). But inspite of its negative impacts, the proper water resources management could help in using the flood water optimally during lean period.

During the last days of July 2010, extreme rainfall occurred over the northwest of Pakistan, in the upper part of the Indus river system (Figures 1, 2). In some areas, more than four times the normal monthly rainfall fell within three days. The instant rain intensity reached $300 \mathrm{~mm}$ over a 36 -hour period according to the Pakistan Meteorological Department (PMD). Similar, excessive precipitation rates were also observed over northern India. For the other parts of Pakistan and India, however, the rainfall was not heavier than in other years, and in Balochistan it was even below average.

Pakistan's Indus River basin was unfortunately badly affected by the heavy monsoon rain that occurred in all her four provinces during late July 2010. The floods were driven by unprecedented monsoon rain. The rainfall anomaly map published by NASA showed unusually intense monsoon rains attributed to La Niña. La Niña is a coupled ocean-atmosphere phenomenon that is the counterpart of El Niño as part of the broader El NiñoSouthern Oscillation climate pattern. During a period of La Niña, sea surface temperatures across the equatorial eastern central Pacific Ocean will be lower than normal by three to five degrees Centigrade. The PMD reported that over 200mm (7.9 inches) of rain fell over a 24-hour period in Khyber Pakhtun Khwa and Punjab. A recordbreaking $274 \mathrm{~mm}$ (10.8 inches) of rain fell in Peshawar during 24 hours; the previous record was $187 \mathrm{~mm}$ (7.4 inches) in April 2009 (Ahmadani 2010; BBC 2010a). Nearly one-fifth of the total land of Pakistan including agricultural, residential and commercial areas was submerged, directly affecting more than 20 million people, causing a death toll of nearly 1,800 people (SRC 2010; BBC 2010b).

This worst flood not only caused damage to the infrastructure, communications systems, irrigation and water supply line, school, hospitals, etc., but it extensively and adversely affected the economic stability to the nation, amounting to an estimated 43 billion US dollar loss to Pakistan (Jakarta Globe 2010). Some of the deadliest floods recorded in Pakistan are noted on Table 1.

Table 1. Deadliest Floods of Pakistan

\begin{tabular}{|l|l|c|}
\hline Year & Event & Death Toll \\
\hline 1950 & 1950 Flood - Pakistan & 2,910 \\
\hline 1977 & Karachi flood & 848 \\
\hline 1992 & $\begin{array}{l}\text { Vajont Dam landslide and monsoon } \\
\text { rainfall - India/Pakistan }\end{array}$ & 1,834 \\
\hline 1993 & South Asian Monsoon Rain & 3,084 \\
\hline 2009 & Karachi monsoon flood & 26 \\
\hline 2010 & Monsoon flooding & 1,800 \\
\hline
\end{tabular}


The Indus Flood of 2010 was caused by heavy monsoon rainfall in the last week of July 2010 in the various parts of Khyber Pakhtun Khwa (KPK), Punjab, Gilgit-Baltistan and Azad Kashmir areas of Pakistan. It was an extreme monsoon rainfall in the last eight decades of Pakistan, as described by the PMD. Figure 1 shows the affected areas of Pakistan during Flood of 2010. And the top five rainfall intensities recorded by the PMD in different parts of the country during Flood of 2010 are shown in the Table 2 and Figure 2. Figures 3 and 4 illustrate the detailed rainfall pattern shift in Pakistan from 1961 to 2020. The figures indicate that the rainfall over the catchment areas of the eastern rivers has decreased or moved away. The probability of occurrence of heavy rainfall events that would lead to floods is more in the western rivers of Pakistan in the near future. The central parts of KPK and northwest Punjab are extremely vulnerable to the flash floods. This pronounced seasonal variation of rain is linked to a persistent south-westerly airflow over the

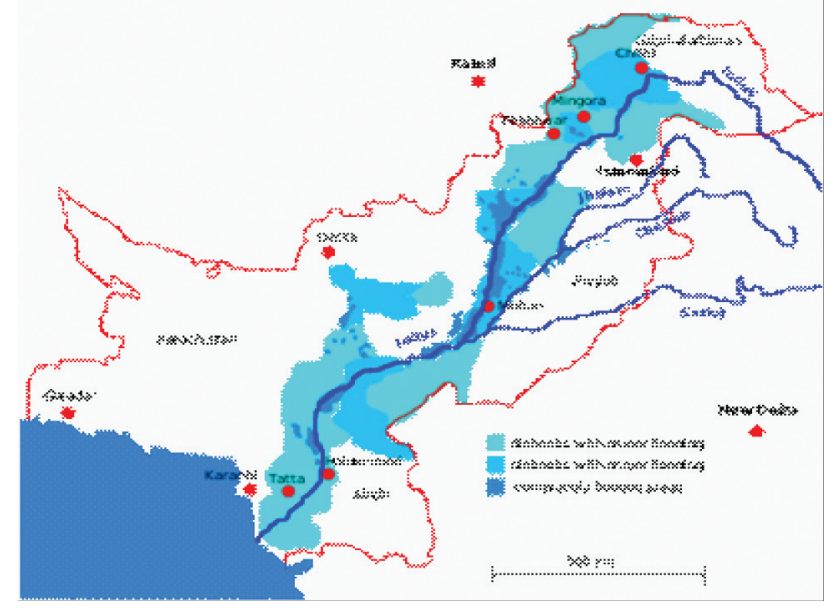

Figure 1. Flood-2010 Affected Areas of Pakistan (Pakistan Meteorological Department)

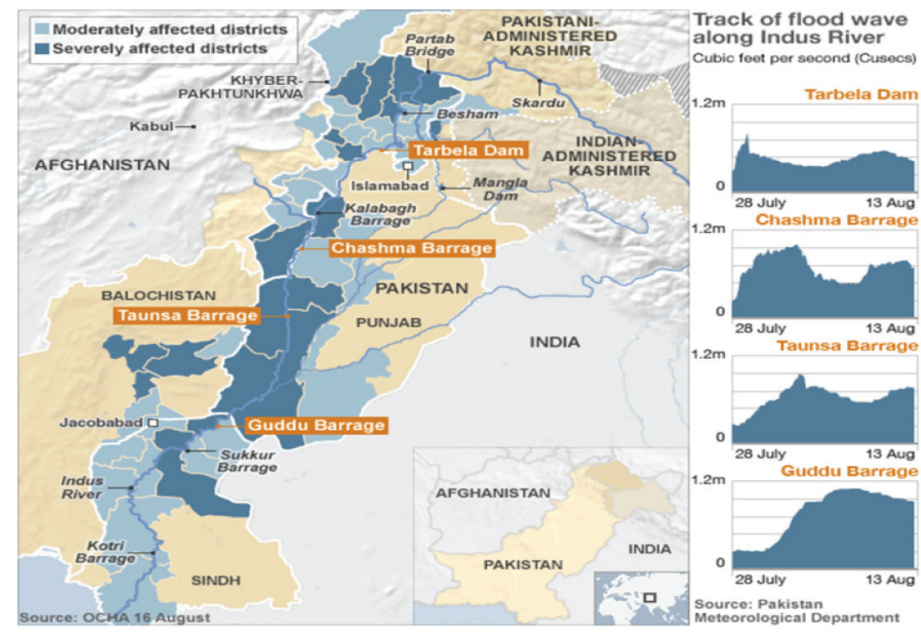

Figure 5. Indus Flood-2010 Hydrograph (Pakistan Meteorological Department)

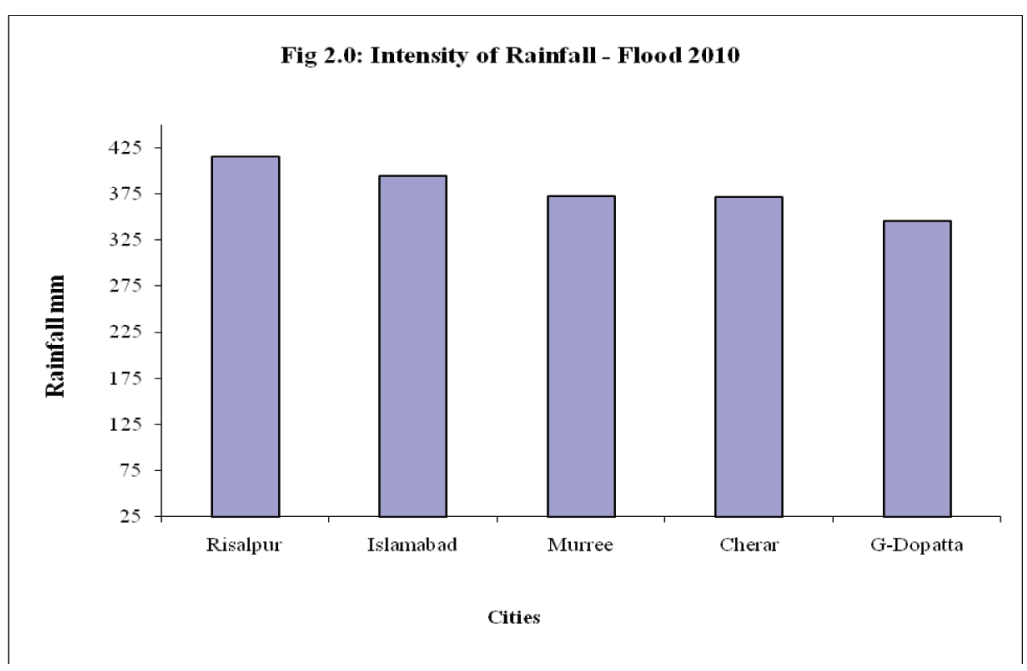

Figure 2. Intensity of Rainfall, Flood-2010 (Pakistan Meteorological Department)
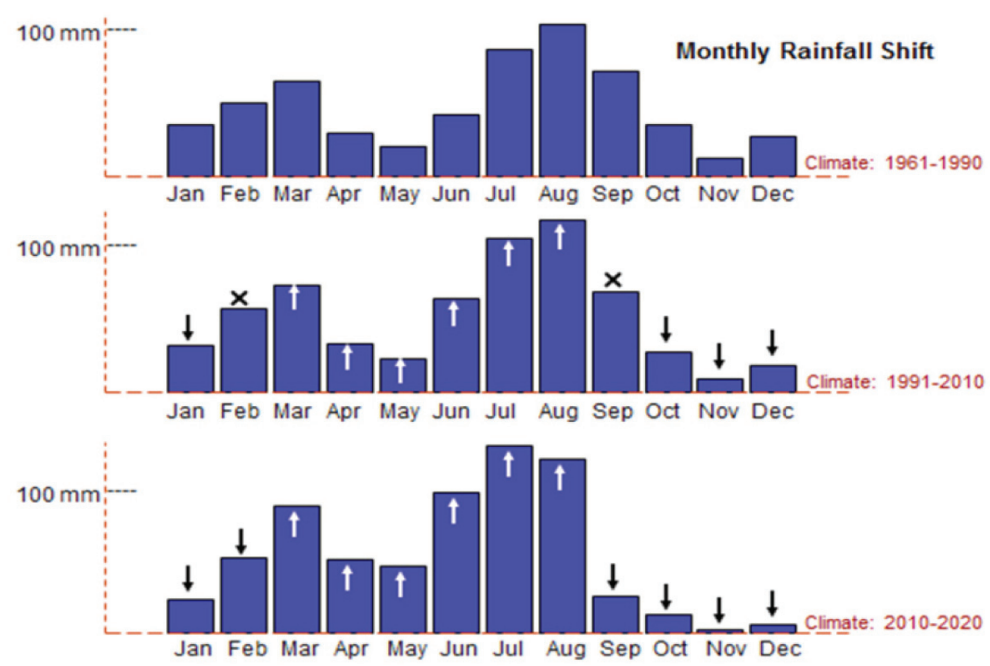

Figure 3. Monthly Rainfall Shift in Pakistan (Pakistan Meteorological Department)

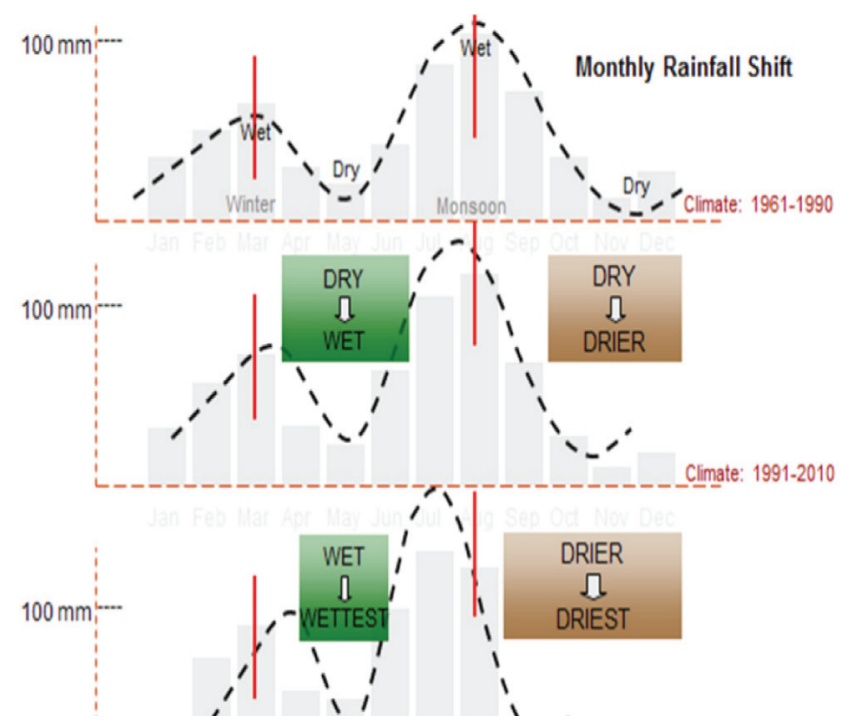

Figure 4. Monthly Rainfall Shift in Pakistan (Pakistan Meteorological Department) 
Table 2. Rainfall Intensity during Flood-2010

\begin{tabular}{|l|l|l|}
\hline City & Province & $\begin{array}{l}\text { Rainfall } \\
(\mathbf{m m})\end{array}$ \\
\hline Risalpur & KPK & 415 \\
\hline Islamabad & Capital & 394 \\
\hline Murree & Punjab & 373 \\
\hline Cherat & KPK & 372 \\
\hline Garhi Dopatta & Azad Kashmir & 346 \\
\hline
\end{tabular}

Arabian Ocean and Bay of Bengal - the so-called Indian monsoon. This flow of already warm moist air picks up further large quantities of water vapor from the ocean surface. Since, the Tibetan plateau enforces the air to ascend and, hence, to condensate, large amounts of rain fall over Southeast Asia. Various factors combined, especially topography and upper-air wind, make that the annual monsoon a complex regional weather pattern.

The discharge of the Flood of 2010 for Tarbela Dam was $24,800 \mathrm{~m}^{3} / \mathrm{s}$. Based on the historic record a flood with a 66-year return period would have a discharge of $18,500 \mathrm{~m}^{3} / \mathrm{s}$. But the discharge of Tarbela Dam during Flood of 2010 shows that it was $30 \%$ higher than the historic values. Figure 5 shows the Flood of 2010 Hydrographs of four different stations of Pakistan.

\section{Damage Caused by the Indus Flood of $\mathbf{2 0 1 0}$}

Some of the notable damages caused by the Indus Flood2010 are these (Jakarta Globe 2010 SRC 2010):

- More than 20 million people severely affected.

- About 1,800 people died.

- More than 2,00o have received severe injuries.

- About six million people displaced.

- About 36 districts heavily affected.

- More than 10 million people forced to take polluted and unhygienic drinking water resulting in water borne diseases like gastroenteritis, diarrhea, skin infections, cholera, etc., as well as an outbreak of malaria.

- About four billion US dollar loss to the infrastructure, including $3916 \mathrm{~km}$ of highways, $5646 \mathrm{~km}$ of railways, and 5,000 schools, etc. (Holbrooke 2010).

- Nearly o.6 million houses destroyed.

- About 10,00okm electric power transmission lines damaged, resulting in $3.135 \mathrm{GW}$ power shortfall.

- Over 500 million US dollar loss to the wheat crop.

- Destruction to cotton, rice, sugar cane, and animal fodder recorded as $3,000 \mathrm{~km}^{2}$, $800 \mathrm{~km}^{2}$, $800 \mathrm{~km}^{2}$ and $1000 \mathrm{~km}^{2}$, respectively; and 500 thousand tons of wheat was destroyed.

\section{Impacts of the Flood of $\mathbf{2 0 1 0}$}

- Due to the large destruction to the agricultural field and products, the prices of the daily commodities rose beyond the level of the common man.

- The agricultural devastation was offset by maximum poppy cultivation, especially in the Federally Admin- istrative Tribal Area and KPK Province.

- A huge financial burden on the country required to re-establish damaged infrastructure.

- Rise in Taliban insurgency due to their engagement in post-flood relief activities, mainly in the areas where either the interest of the government was missing or was seen to be corrupt (Hasnain 2010).

- The inefficiency of the local political leaders caused political unrest in most parts of the country, the flood effected people shows little attention towards their leaders promises now.

- This flood has created million of job chances/opportunities for youth.

- The GDP growth rate, rated at $4 \%$ before the Flood2010, fell as predicted to a negative level.

\section{Conclusions}

The Indus Flood of 2010 was no doubt the most severe flood in the recent history of Pakistan, bringing destruction to a large extent in the country, destroying lives, infrastructure, agricultural land, communication systems, and much more. It left a number of potential water borne diseases in different part of the country by contaminating both the ground and surface water resources of the public water supply schemes. The destruction caused by the Flood-2010 in Pakistan could take longer time to cope up the required deficiencies; but greater determination by the government, optimum use of the available resources, proper and efficient management system, will power of the people, and honesty of the administration authorities could go a long way to counter balance and help mitigate its disastrous effects.

Engr. Arshad Ali is a professional environmental engineer, graduated from the University of Engineering and Technology, Peshawar, Pakistan. He has both a Masters degree in Environmental Engineering and an E-MBA, with specialization in Environmental Project Management. He has taught and conducted research in various institutes and organizations of international repute. He is the author of several international research publications. Presently, he is serving as an Assistant Professor at the National University of Sciences and Technology, Islamabad, Pakistan.

Corresponding Address: aliarshado8@yahoo.com.

Ms. Ghazala Nosheen has a Masters degree in Chemistry from the University of Peshawar, Pakistan, and is serving as Faculty Member at Fazia Degree College Risalpur. She is currently enrolled at the Northern University Nowshera as a potential research scholar of Environmental Sciences. She has both research and teaching experience in the field of environmental sciences.

Engr Kashif Ahmad Khan is a Graduate Civil Engineer with a Masters degree in Transportation Engineering. He has more than 25 years of professional 
experience on various projects of civil and environmental engineering projects, and is now serving as Senior Instructor in the College of Civil Engineering (MCENUST) Risalpur, Pakistan.

\section{References}

Ahmadani, A., 2010, Heavily funded FFC fails to deliver, The Nation (Pakistan, August 19, 2010). URL: www. nation.com.pk.

BBC, 2010a, Flooding kills hundred in Pakistan and Afghanistan, BBC News Online (London: July 30, 2010). URL: www.bbc.co.uk.

BBC, 2010b, Millions of Pakistan children at risk of flood diseases, BBC News Online (London: News Online (August 16, 2010). URL: www.bbc.co.uk.

Hasnain, K., 2010, Taliban courts Pakistan flood victims, Spiegel Online International, Germany (August 16, 2010). URL: www.spiegel.de/international/search/ index.html? suchbegriff $=$ Taliban + courts + Pakistan $+\mathrm{f}$ lood+victims+.

Holbrook, Richard, 2010, Interview: The Rachel Maddow Show, New York, NY: MSNBC-TV (October 3, 2010). URL: www.msnbc.msn.com.

Jakarta Globe, 2010, Pakistan battles economic pain of floods, Jakarta, Indonesia: The Jakarta Globe (August 19, 2010). URL: www.thejakartaglobe.com.

SRC, 2010, Pakistan floods: The deluge of disaster Facts \& figures as of 15 September 2010, Siongapore: Singapore Red Cross. URL: http://reliefweb.int/ node $/ 368203$.

Tallat, M.S., H.N. Hashmi and A. Ali, 2011, Assessment of flashflood hazard in Pakistan, Proceedings of the International Conference on Water Resources Engineering and Management (ICWREM-2011), March 7-8, 2011, Department of Civil Engineering, UET Lahore, Pakistan.

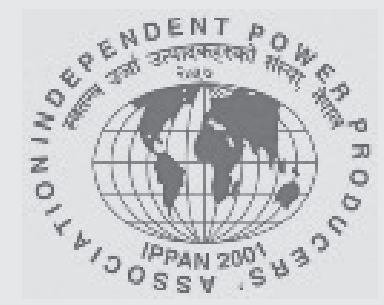

\section{The Independent Power Producers' Association, Nepal}

\section{IPPAN is a membership organization of the Independent Power Producers and other stakeholders involved in Nepal's hydropower development.}

IPPAN's advocacy and lobbying efforts in the past led to:

- IPPAN's involvement in various committees formed by the Government to reform Nepal's power sector,

- IPPAN President as Co-chairman of the Infrastructure Working Group of the Nepal Business Forum

- Involvement of IPPAN in the drafting of the proposed Electricity Bill and NERC Bill.

- Cross Border Transmission Line Project at advanced level of Implementation

- Establishment of Hydropower Investment and Development Company Ltd.

- Cancellation of capital investment requirement during business registration/ survey license period.

- Competitive and Transparent Bidding of hydropower projects

- Cancellation of Local development Tax, Levies and Octroi etc.

- Government announcement of Income tax holidays

- Revision of Performance Bond by NEA

IPPAN organized various programs in the past which resulted in better visibility of IPPAN.

Notable among them are:

- The $4^{\text {th }}$ International Hydropower Convention (2009)

- Power Summits 2008, 2007, and 2006

- Hydropower Project Financing 2008

- Friday Forum, interactive discussion program held fortnightly 